\title{
The Effect of VAT on Total Factor Productivity in China-Based on the One-step Estimation Method
}

\author{
Yan-Feng JIANG ${ }^{a}$, Yan-Fang JIANG \\ Department of Public Economics in Xiamen University, Xiamen city, China \\ Institute of Public Administration in Henan University of Economics and Law, Zhengzhou city, China \\ ajiangyanfeng2011@126.com,18239901259@163.com
}

Keywords: Value-added tax, Production efficiency, Technical efficiency, Scale efficiency, One step estimation method.

\begin{abstract}
This paper empirically test how the change of the proportion of the value added tax impacts on each part of China's productivity based on the one step estimation method,. The results show, the higher the proportion of the value added tax, the more conducive to the improvement of production efficiency. But it is not good for the technical efficiency and scale efficiency. We should implement value added tax subsidy for technology research and development (R\&D) and focus on the adjustment effect of value added tax on the specialized division of labor.
\end{abstract}

\section{Introduction}

In the numerous factors influencing productivity, tax, as the most important part of the economic system, its influence can not be ignored. The reform of the tax system in 1994 established the basic framework of the current tax system. In the framework of the existing tax system, the effect of VAT on China's economy has been the major concern constantly. One important reason is that, value added tax is the major tax in china's tax system.

Value added tax is based on the added value in production and circulation. The legal nominal tax rate is $17 \%$, and $13 \%$ is the low tax rate in China. Today's popular for value added tax is due to it can optimize the efficiency of tax structure, and it also can reduce the marginal cost of government financing (Keen and Lockwood, 2010)[1], even American experts worry the convenience of value added tax financing and consequently become the "the printing presses" for the government (President's Advisory Panel, 2006)[2].Value added tax is only a tax on final consumption, so as long as the design is appropriate, VAT is a particularly efficient tax. This implicates the value-added tax is a powerful method to promote economic growth. Taxing on intermediate transactions, business tax will lead to the loss of the production efficiency. Sales tax also inevitably leads to loss of productivity due to the difficulty in distinguishing the final sales (Ring,1999)[3], So in practice, value added tax is often used to replace the business tax and the single stage sales tax.

But some scholars believe that, value added tax in simplicity and universality has the potential advantages compared with the turnover tax, but the comparative advantage is not dramatically remarkable in economic efficiency. In some countries, particularly developing countries, Value added tax is the core content of the modern tax management system with it could simplify the tax management, improve tax compliance. But, Value added tax has some potential disadvantages and is not conducive to efficiency. When the transaction chain once broken, value added tax will lead to the loss of the production efficiency. In addition, because tax system is not perfect, and the statutory tax rebate is too high, these means the value-added tax will not help the export and trade, hence reduce exports and domestic output (Desai-Hines, 2005[4]).Meanwhile, Value added tax will have a negative impact on informal sector of the economy (Piggott and Whalley,2001[5]; Emran and Stiglitz, 2005[6]; Keen, 2008[7]).

Therefore, based on the not clear performance of value added tax, whether value added tax is conducive to the improvement of the efficiency is only one empirical study, how to explore the efficiency gain or efficiency loss is a problem in the experience (Keen and Lockwood,2010)[1]. 
We will from the provincial level specially probe into how the change of the proportion of the value added tax impacts on each part of China's productivity, and observe how the change of the proportion of the value added tax impacts on each part of China's productivity.

\section{The Model Specification}

\section{The Decomposition of Total Factor Productivity}

Solow(1957)formally proposed the aggregate production function with constant returns to scale and growth equation, and thus decompose the concept of total factor productivity: it is an important index to measure the productivity. For a long time, the neoclassical economic growth theory saw the growth rate of total factor productivity as the technology progress. Many studies do not distinguish the total factor productivity, in fact, total factor productivity can be decomposed into production efficiency, technical progress, scale efficiency and resource production efficiency (Kumbhakar and Lovell,2000)[8]. Kumbhakar and Lovell(2000) [8] obtained the decomposition formula of he growth rate of total factor productivity:

$$
T F P_{i t}=T E_{i t}+T P_{i t}+(E-1) \sum_{j} \frac{E_{j}}{E} x_{j}, \quad j=1,2
$$

Here, $T F P_{i t}$ represents the change rate of total factor productivity, $T E_{i t}$ denotes the change rate of production efficiency, $T P_{i t}$ is the rate of technological advance, $E_{j}(j=1,2)$ presents the output elasticity of capital and labor respectively, $E$ indicates the scale elasticity, $x_{j}$ is the change rate of inputs factor $j$.

\section{The Trans-Log Production Function}

We put the concrete form of the trans-log production function is:

$$
\begin{aligned}
\ln Y_{i t}= & \beta_{0}+\beta_{1} \ln K_{i t}+\beta_{2} \ln L_{i t}+\beta_{3} t+\beta_{4} \frac{\ln ^{2} K_{i t}}{2}+\beta_{5} \frac{\ln ^{2} L_{i t}}{2} \\
& +\beta_{6} \frac{t^{2}}{2}+\beta_{7} \ln K_{i t} \ln L_{i t}+\beta_{8} t \ln K_{i t}+\beta_{9} t \ln L_{i t}+\varepsilon_{i t}
\end{aligned}
$$

Here, $Y_{i t}, K_{i t}, L_{i t}$ represents real output, real capital and labor for province $i$ in time $t$ respectively. $t$ is the time trend, denotes technology progress.

Based on the type of trans-log production function, then we can define capital output elasticity, labor output elasticity, scale elasticity for province $i$ in time $t$. In addition, we can also define technology progress rate as follows:

$$
\begin{aligned}
& E_{K i t}=\frac{\partial \ln Y_{i t}}{\partial \ln K_{i t}}=\beta_{1}+\beta_{4} \ln K_{i t}+\beta_{7} \ln L_{i t}+\beta_{8} t \\
& E_{L i t}=\frac{\partial \ln Y_{i t}}{\partial \ln L_{i t}}=\beta_{2}+\beta_{5} \ln L_{i t}+\beta_{7} \ln K_{i t}+\beta_{9} t \\
& E_{i t}=E_{K i t}+E_{L i t} \\
& T P_{i t}=\frac{\partial \ln Y_{i t}}{\partial \ln t}=\beta_{3}+\beta_{6} \ln t+\beta_{8} \ln K_{i t}+\beta_{9} \ln L_{i t}
\end{aligned}
$$


In the expressions above, $E_{K i t}, E_{L i t}, E_{i t}$ and $T P_{i t}$ denotes capital output elasticity, labor output elasticity, scale elasticity and technology progress rate respectively for province $i$ in time $t$.

\section{The Stochastic Frontier Analysis}

The basic idea for SFA is assuming the input factor $X_{i t}$ can produce $Y_{i t}$ in the most effective cases. The distance between sample points and random boundary is efficiency loss. As a part of random errors, the efficiency loss is taken into account in the model. Formally, SFA can be expressed as follows:

$$
Y_{i t}=X_{i t} \beta+\omega_{i t}-v_{i t} \quad i=1,2, \cdots, N ; t=1,2, \cdots T
$$

Here, $\beta$ is the parameter to be estimated, $Y_{i t}$ is the actual output, correspondingly in this paper, is the logarithm of real output for province $i$ in time $t ; X_{i t}$ is the input factor, it refers to the actual capital stock, labor force, time trend and the logarithm of its quadratic term and cross term correspondingly. $\omega_{i t}$ is the random error term, follows a standardized normal distribution $N\left(0, \sigma_{w}^{2}\right)$, independent to $v_{i t} ; v_{i t}$, the inefficiency item for province $i$ in time $t$, and the distribution of $v_{i t}$ could have four kinds in different situations: half normal distribution, truncated normal distribution, exponential distribution and gamma distribution. In this paper, we assume $v_{i t}$ obeys the half normal distribution $N\left(\mu_{i t}, \sigma_{v}^{2}\right)$, and is a nonnegative random variable. According to Battese and Coelli [9] $v_{i t}$ can be expressed further as:

$$
v_{i t}=Z_{i t} \gamma+\varepsilon_{i t}
$$

Here, $\gamma$ is the parameter to be estimated, $Z_{i t}$ is each factor that affects the inefficiency item, independent of the production process. This paper introduces the following variables as the factors that affect the inefficiency item: The proportion of State owned industrial output value accounted for the total industrial output value, the proportion of fiscal expenditure accounted for GDP, the proportion of exports accounted for GDP, the initial human capital, the initial physical capital, the ratio of value added tax accounted for tax revenue, the regional dummy variables; $\varepsilon_{i t}$ obeys the normal distribution $N\left(0, \sigma_{\varepsilon}^{2}\right)$. The technical efficiency term can be defined as:

$$
T E_{i t}=\exp \left\{-v_{i t}\right\}=\exp \left\{-Z_{i t} \gamma-\varepsilon_{i t}\right\}
$$

\section{Estimation Method}

For the estimation of production function and the inefficiency production function, we use the one step estimation method with maximum likelihood estimation or nonlinear least squares estimation. In addition, we follow the panel data model to predict technical progress equation and scale efficiency equation.

\section{Data Specification}

We used the data mainly from the China's statistical yearbook, provincial statistical yearbook, "Compilation of statistical data in recent sixty years of China", the network database etc. We adopted the panel data of provinces, and the section is not included Tibet and Hainan, Chongqing and Sichuan provinces were combined, including 28 provinces, municipalities and autonomous regions. The initial time is 1994 in which year the reform of localized fiscal tax system was started, and the ending year is 2011.consisting 18 years of data. 


\section{Empirical Test for the Effect of the Proportion of the Value Added Tax on Productivity}

According to the above, to test the effect of the VAT on productivity efficiency, we construct the following four econometric models. Combining the trans-log production function and SFA model, we construct an empirical model for production function and the production inefficiency equation as follows

$$
\begin{aligned}
\ln Y_{i t}= & \beta_{0}+\beta_{1} \ln K_{i t}+\beta_{2} \ln L_{i t}+\beta_{3} t+\beta_{4} \frac{\ln ^{2} K_{i t}}{2}+\beta_{5} \frac{\ln ^{2} L_{i t}}{2} \\
& +\beta_{6} \frac{t^{2}}{2}+\beta_{7} \ln K_{i t} \ln L_{i t}+\beta_{8} t \ln K_{i t}+\beta_{9} t \ln L_{i t}+\omega_{i t}-v_{i t} \\
v_{i t}= & \gamma_{0}+\gamma_{1} \ln \text { vat }_{i t}+\gamma_{2} \text { market }_{i t}+\gamma_{3} \text { government }_{i t}+\gamma_{4} \text { openness }_{i t}+\gamma_{5} h c_{i t}+\gamma_{6} m c+\gamma_{7} \text { east }_{i t}+\gamma_{8} \text { west }_{i t}+\varepsilon_{i t}
\end{aligned}
$$

The technical efficiency equation is:

$$
T P_{i t}=\alpha_{0}+\alpha_{1} \ln \text { vat }_{i t}+\alpha_{2} \text { market }_{i t}+\alpha_{3} \text { government }_{i t}+\alpha_{4} \text { openness }_{i t}+\alpha_{5} h c_{i t}+\alpha_{6} m c+\alpha_{7} \text { east }_{i t}+\alpha_{8} \text { west }_{i t}+u_{i t}+\xi_{i t}
$$

The scale efficiency equation is:

$$
S E_{i t}=\alpha_{0}+\alpha_{1} \ln v t_{i t}+\alpha_{2} \text { market }_{i t}+\alpha_{3} \text { government }_{i t}+\alpha_{4} \text { openness }_{i t}+\alpha_{5} h c_{i t}+\alpha_{6} m c+\alpha_{7} \text { east }_{i t}+\alpha_{8} \text { west }_{i t}+w_{i t}+\xi_{i t}
$$

The trans-log production function is estimated by one step method. Manufacturing efficiency value, technology change value and scale efficiency change value can be estimated based on the analysis above. And then estimate the efficiency equations. The estimation results are showed in Table 1.

\section{The Analysis of Trans-Log Production Function Estimation}

Most variables and their quadratic items in the production function are very significant, the average capital output elasticity is 0.468 , the average labor output elasticity is 0.438 .

\section{The Analysis of the Production (In) Efficiency Equation Estimation}

From the production efficiency estimation results, the average production efficiency is 0.903 .We mainly focus on the effect of the proportion of the value added tax on production efficiency. From Table1, we can conclude: The proportion of the value added tax has a positive impact on production efficiency, and the positive effect is remarkable. This may be relevant to the transformation and reform of value added tax in recent years, and also because the value added tax system is more flexible than other tax system.

Effect of other variables on productivity is not significant, except the significant robust positive effect of the initial human capital on production efficiency. Our estimation results show, the larger the proportion of state owned industrial output value accounted for industrial output value, the higher the production efficiency; the larger the proportion of fiscal expenditure accounted for GDP, the higher the production efficiency; In addition, the results also show the deepening of the opening up is conducive to the improvement of production efficiency. The province with higher initial human capital its production efficiency is also higher.

\section{The Analysis of Technical Efficiency Equation Estimation}

The Hausman test suggested that we should use the fixed effect model to estimate technical efficiency equation, therefore, we omit the regional dummy variables and the initial capital stock. 
From the estimation results, the larger the proportion of the value added tax, the less conducive to the technological progress, and the conclusion not only significant but robust. With the transformation of value added tax, investment in fixed assets not only can improve the profitability of enterprises, but can enjoy the value added tax deduction. Relatively speaking, technology research and development should face the risk of research activity, but there is not enough subsidy for R\&D to compensate for this risk in the value added tax system. Therefore, the value-added tax does not have comparative advantages over other taxes on promoting technological progress.

\section{The analysis of scale efficiency equation estimation}

Table 1: Estimation of the production function and efficiency equation

\begin{tabular}{|c|c|c|c|c|}
\hline & $\begin{array}{l}\text { The trans-log } \\
\text { production } \\
\text { function } \\
\text { estimation }\end{array}$ & $\begin{array}{l}\text { The production } \\
\text { (in) efficiency } \\
\text { equation } \\
\text { estimation }\end{array}$ & $\begin{array}{l}\text { Technical } \\
\text { efficiency } \\
\text { equation } \\
\text { estimation }\end{array}$ & $\begin{array}{c}\text { Scale efficiency } \\
\text { equation } \\
\text { estimation }\end{array}$ \\
\hline $\ln K$ & $\begin{array}{c}2.430 * * * \\
(-0.453)\end{array}$ & & & \\
\hline $\operatorname{lnL}$ & $\begin{array}{c}-1.294^{* * * *} \\
(0.419)\end{array}$ & & & \\
\hline $\mathrm{t}$ & $\begin{array}{c}-0.342^{* * * *} \\
(-0.068)\end{array}$ & & & \\
\hline$(\ln K)^{2}$ & $\begin{array}{l}-0.172^{*} \\
(-0.088)\end{array}$ & & & \\
\hline$(\operatorname{lnL})^{2}$ & $\begin{array}{l}0.351^{* * * *} \\
(-0.066)\end{array}$ & & & \\
\hline $\mathrm{t}^{2}$ & $\begin{array}{c}0.003 \\
(0.003)\end{array}$ & & & \\
\hline $\operatorname{lnKlnL}$ & $\begin{array}{c}-0.134^{* * * *} \\
(0.041)\end{array}$ & & & \\
\hline $\operatorname{tln} K$ & $\begin{array}{l}0.028^{* * *} \\
(0.013)\end{array}$ & & & \\
\hline $\operatorname{tln} \mathrm{L}$ & $\begin{array}{c}0.017^{* * * *} \\
(0.006)\end{array}$ & & & \\
\hline lnvat & & $\begin{array}{l}-3.200^{* * *} \\
(1.451)\end{array}$ & $\begin{array}{c}-0.033^{* * * * *} \\
(0.005)\end{array}$ & $\begin{array}{c}-0.011^{* * * * *} \\
(0.003)\end{array}$ \\
\hline market & & $\begin{array}{l}-1.891 \\
(1.983) \\
\end{array}$ & $\begin{array}{c}-0.146^{* * * *} \\
(0.010)\end{array}$ & $\begin{array}{l}0.022^{* * * *} \\
(0.005)\end{array}$ \\
\hline government & & $\begin{array}{l}-7.293 \\
(6.085)\end{array}$ & $\begin{array}{c}0.392^{\text {**** }} \\
(0.022)\end{array}$ & $\begin{array}{c}0.050^{\text {***** }} \\
(0.011)\end{array}$ \\
\hline openness & & $\begin{array}{l}-3.053 \\
(3.671)\end{array}$ & $\begin{array}{c}0.041^{* * * *} \\
(0.012)\end{array}$ & $\begin{array}{c}0.005 \\
(0.006)\end{array}$ \\
\hline hc & & $\begin{array}{c}-13.229^{* * * *} \\
(3.641)\end{array}$ & $\begin{array}{l}-0.051^{*} \\
(0.026)\end{array}$ & $\begin{array}{c}-0.078^{* * * * *} \\
(0.013)\end{array}$ \\
\hline $\mathrm{mc}$ & & $\begin{array}{l}-0.005 \\
(0.005)\end{array}$ & & $\begin{array}{c}0.000^{* * * *} \\
(0.000)\end{array}$ \\
\hline $\begin{array}{l}\text { Hausman } \\
\text { statistics }\end{array}$ & & & 50.13 & 10.39 \\
\hline $\begin{array}{l}\text { Panel } \\
\text { model }\end{array}$ & & & $\mathrm{F}$ & $\mathrm{R}$ \\
\hline
\end{tabular}

Notes: ${ }^{* * * * * *}$ represents the confidence level at $10 \%, 5 \%$ and $1 \%$ respectively

The Hausman test suggests random effect in the estimation of scale efficiency equation. Therefore, we use the generalized least square method to estimate the model. 
We found that, the larger of the value added tax, the less conducive to the scale efficiency. and the effect is significant and robust. According to Smith theorem, the scale efficiency is relative to specialization, and specialization can promote the scale efficiency. Theoretically value added tax is only tax on added value, so it should be able to promote the specialization of labor division. While China's value added tax is not conducive to improve scale efficiency, this may be related to China's specific design of value added tax system.

For the control variables, the degree of nationalization and government expenditure ratio are both beneficial to the improvement of the scale efficiency. Effect of openness on the scale efficiency is positive, but not significant. The higher the initial stock of human capital, then it would the less conducive to the scale efficiency. The higher the initial capital stock, the more benefit to scale efficiency.

\section{Summary}

Value added tax is an important part of the tax structure in China, and it has an important impact on total factor productivity. In fact, productivity can be decomposed into production efficiency, technical efficiency and scale efficiency. How value added tax will affect productivity, this problem might rely heavily on empirical analysis. Based on the one step estimation method, we analyse how value-added tax in the tax structure impact on each part of total factor productivity.

Our empirical results show that: (1) the proportion of the value added tax has significant and positive effect on production efficiency on average. This may be relative to the transformation and reform for value-added tax, and the flexibility of value-added tax system than other tax system. (2) The proportion of the value added tax has a significant negative impact on technical efficiency on average. This may be because that technology R\&D faces the research risks, but the value added tax dose not render enough tax concessions for technology $R \& D$, and can not compensate for the technology R\&D risks, therefore, the value added tax does not have an advantage over other taxes on the promotion of technological progress. (3) On average, the proportion of the value added tax has a significant negative impact on scale efficiency. This may because that the design of China's value added tax system is not conducive to specialization, thus China's value added tax is not conducive to improve scale efficiency. To sum up, the effect of proportion of value added tax in the tax structure on China's total factor productivity is complex.

In recent years, the China's government has carried out a series of adjustments for the value added tax system, including the transformation and expansion of value added tax, etc. These reforms really help reduce the tax burden, but how value added tax affect the productivity should not be ignored. We suggest, with the reform "business tax change into valve added tax" and the expansion of the value added tax, we should focus on the design that can optimize the tax system. Productivity is the core of economic growth, and the value added tax system should not hinder the productivity progress. For example, it is appropriate to supply tax subsidy for enterprises' technology R\&D, to avoid the enterprise employ capital to replace technology $R \& D$, and to encourage enterprises to increase $R \& D$ investment. In addition, the design of added value tax should be conducive to the specialization. Be sure that added value tax only tax on the final transactions, should avoid double taxation, and encourage the improvement of scale efficiency.

\section{References}

[1] Keen, Michael, Lockwood, Ben, The value added tax: Its causes and consequences. Journal of Development Economics 92, 2010, pp.138-151.

[2] President's Advisory Panel on Federal Tax Reform, Fair and Pro-Growth: Proposals to Fix America's Tax System. 2006.

[3] Ring, Raymond J.,.The proportion of consumers' and producers' goods in the general sales tax. National Tax Journal 42, 1999, pp.167-179. 
[4] Desai, Mihir A., Hines, James R. Jr., Value added taxes and international trade: the evidence. mimeo: University of Michigan, 2005.

[5] Piggott, John, Whalley, John, VAT base broadening, self supply, and the informal sector. American Economic Review 91, 2001, pp.1084-1094.

[6] Emran, Shahe M., Stiglitz, Joseph E., On selective indirect tax reform in developing countries. Journal of Public Economics 89, 2005, pp.599-623.

[7] Keen, Michael,VAT, tariffs, and withholding: Border taxes and informality in developing countries. Journal of Public Economics 92 (2), 2008, pp.1892-1906.

[8] S. C. Kumbhakar, C. A . K. Lovell, Stochastic Frontier Analysis. Cambridge University Press, 2000.

[9] Battese, G., Coelli, T., A model for technical inefficiency effects in a stochastic frontier production function. Empirical Economics 20, 1995, PP.325-332. 